\title{
Surgical complications in systemically compromised patients: analysis of 992 medical records
}

\author{
Complicações cirúrgicas em pacientes comprometidos \\ sistemicamente: análise de 992 prontuários
}

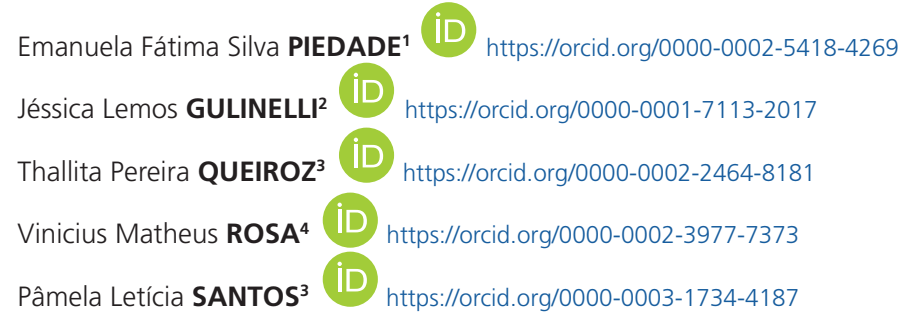

\section{ABSTRACT}

Objective: The preoperative evaluation is essential to prevent postoperative surgical complications. The present study aimed to establish quantitative and qualitative profiles of systemic disorders and relate them to postoperative surgical complications in patients subjected to dental extraction. Methods: Data were collected from the medical records of 992 patients subjected to dental extractions from 2010 to 2015 through a detailed analysis of anamnesis files. The data collected were tabulated and converted to percentages to facilitate the discussion and comparison with reports in the literature. Results: From all the medical records analyzed, 559 presented systemic changes, which corresponds to $56.3 \%$. Among them, there was a higher prevalence of patients with hypertension (24\%), smoking habits (20\%), and diabetes (11\%). The most frequent complications were pain (34\%), inflammation (19.8\%), and hemorrhage (13.2\%). The prevalence of diseases related to age shows patients under the age of $20(4.7 \%), 20$ to 29 (11.3\%), 30 to 39 (16.8\%), 40 to $44(10 \%), 45$ to $49(10.9 \%), 50$ to $54(12.3 \%), 55$ to $59(12.9 \%), 60$ to $64(10.4 \%), 65$ to $69(4.8 \%)$, and older than 70 years old $(5.9 \%)$. As for systemic changes with complications, hypertensive patients with complications $(n=11)$ showed higher prevalence of pain $(45.4 \%)$, the most common complication in smokers $(n=15)$ was exacerbated inflammation $(33.3 \%)$, and $50 \%$ of diabetic patients with complications $(n=8)$ were diagnosed with alveolitis. Conclusion: The method studied allowed concluding there was a relationship between postoperative complications and systemic changes, and the main ones were pain-hypertension, inflammation-smoking, and alveolitis-diabetes.

Indexing terms: Epidemiology. Preoperative care. Surgery, oral.

\section{RESUMO}

Objetivo: A avaliação pré-operatória é de fundamental importância para a prevenção das complicações cirúrgicas pós-operatórias. O objetivo do presente estudo foi estabelecer um perfil quantitativo e qualitativo das enfermidades sistêmicas e relaciona-las com

$\operatorname{rrv}$

1 Clínica Privada, Bauru, SP, Brasil.

2 Clínica Privada, Londrina, PR, Brasil.

3 Universidade de Araraquara, Faculdade de Odontologia, Departamento de Ciências da Saúde. Av. Maria Antônia Camargo de Oliveira, 170 , 14807-120, Vila Suconasa, Araraquara, SP, Brasil. Correspondence to: PL Santos. E-mail: <pamelalsantos@hotmail.com>.

${ }^{4}$ Centro Universitário de Bauru, Faculdade de Odontologia, Departamento de Ciências da Saúde. Bauru, SP, Brasil.

$\boldsymbol{\nabla} \boldsymbol{\nabla} \boldsymbol{\nabla}$

How to cite this article

Piedade EFS, Gulinelli JL, Queiroz TP, Rosa VM, Santos PL. Surgical complications in systemically compromised patients: analysis of 992 medical records. RGO, Rev Gaúch Odontol. 2020;68: e20200031. http://dx.doi.org/10.1590/1981-863720200003120190005 
complicações cirúrgicas pós-operatórias em pacientes submetidos exodontia. Métodos: Para isso foram coletados dados de 992 prontuários de paciente submetidos a exodontias no período de 2010 a 2015, por meio da análise minuciosa da ficha de anamnese. Os dados obtidos foram tabulados e transformados em porcentagem, para facilitar a discussão e comparação com os relatos da literatura. Resultados: No total de prontuários analisados, 559 apresentaram alterações sistêmicas, o que corresponde a 56,3\%. Dentre elas, houve uma maior prevalência de pacientes com hipertensão (24\%), tabagismo (20\%) e diabetes (11\%). As complicações mais frequentes foram dor (34\%), inflamação (19,8\%) e hemorragia (13,2\%). Considerando-se a prevalência de doenças relacionadas à idade, a faixa etária de menor de 20 anos (4.7\%), 20 a 29 (11.3\%), 30 a 39 (16.8\%), 40 a 44 (10\%), 45 a 49 (10.9\%), 50 a 54 (12.3\%), 55 a 59 (12.9\%), 60 a 64 (10.4\%), 65 a 69 (4.8\%), e maiores de 70 anos (5.9\%). Relacionando as alterações sistêmicas com as complicações, dentre os pacientes hipertensos que apresentaram complicações $(n=11)$, a dor foi a mais prevalente $(45,4 \%)$. Já nos fumantes ( $n=15)$ a complicação mais comum foi a inflamação exacerbada (33,3\%). Nos diabéticos com presença de complicações ( $n=8)$, $50 \%$ foram diagnosticados com alveolite. Conclusão: Com base na metodologia estudada foi possível concluir que houve relação das complicações pós-operatórias e alterações sistêmicas, sendo as principais dor-hipertensão, inflamação-tabagismo e alveolite-diabetes.

Termos de indexação: Epidemiologia. Cuidados pré-operatórios. Cirurgia bucal.

\section{INTRODUCTION}

Dental procedures date back from last century and they are performed all over the world. A safe and predictable dental practice requires a well-prepared professional staff, correct diagnosis, and a detailed treatment plan based on the systemic, local, and psychological conditions of the patient [1]. Thus, the professional will feel safer to perform the dental surgical procedure, with consequent benefit to the patient [2].

Despite the high success rate of dental surgeries, some risk factors predispose the occurrence of complications, highlighting the inadequate preparation of professionals and patients. Among the risk factors, special attention should be given to the preoperative preparation of systemically compromised patients [3].

Currently, it is possible to observe a higher prevalence of patients with chronic diseases such as diabetes and cardiovascular complications. This is mainly due to the increased life expectancy of the general population, which has become more numerous and seeks dental care with higher frequency $[3,4]$.

The preoperative evaluation of systemically compromised surgical patients is performed with a patient completing a form or participating in a direct interview. Deciding on the choice of appropriate and specific laboratory tests may be difficult, considering the literature shows contradictions about the treatment protocols applied to these patients [3]. The reported and diagnosed systemic changes during this step may affect the indication of a certain procedure and the dental treatment proposed, compromising patient well-being [5-7].

Therefore, it is important to verify what systemic diseases affect the population most frequently, considering their relationship with age and correlating them with postoperative surgical complications to raise the awareness of dental surgeons on the importance of performing anamnesis and investigating these changes before implementing the treatment plan. In addition, the prevalence of systemic changes is significant for diagnosis and therapeutic management, preparing dental surgeons to prevent potential postoperative surgical complications.

Thus, this study aimed to establish quantitative and qualitative profiles of systemic changes and relate them to the postoperative surgical complications in patients subjected to dental surgical treatment.

\section{METHODS}

This study was developed through the analysis of the medical records of patients subjected to dental treatment from 2010 to 2015, performed in the subjects of Oral Surgery and Traumatology of the Sagrado Coração University. The research project in question was submitted to and approved by the Human Research Ethics Committee (report number 1.045.243).

The inclusion criteria were: 1) medical records of patients subjected to oral surgery in the last five years (2010-2015) at the surgery clinics of the Sagrado Coração University; and 2) complete anamnesis records of patients, with the consent form signed and agreeing that clinical profile data could be used in scientific research without patient identification. In contrast, the exclusion criteria were: 1) medical records of patients assisted outside the period of the study; 2) patients under treatment; and 3) incomplete anamnesis records.

Undergraduate or graduate students and/or professors in charge of the subject of Surgery at the Sagrado 
Coração University filled out the medical records analyzed. The factors considered were primary systemic diseases affecting the world population, such as hypertension, heart diseases, endocrine diseases, osteoporosis, respiratory diseases, and drug allergies, which were related to age group and potential postoperative surgical complications.

The data collected were tabulated and converted to percentages to facilitate the discussion and comparison with reports in the literature $[8,9]$.

\section{RESULTS}

This study analyzed 992 medical records of patients subjected to simple dental extractions. From the total of records, 559 patients showed systemic changes, which correspond to $56.3 \%$ of the total number of patients, and some of them presented concurrent diseases.

The systemic change with the highest prevalence was hypertension, reported by $24 \%$ of patients with positive medical history, followed by smoking habits (20\%) and diabetes (11\%) (figure 1).

As for age group, the medical records of patients aged between 30 to 39 years were the most prevalent, including 188 records (18.2\%). In contrast, the medical records of patients aged between 65 and 69 years were the least prevalent, including 33 records (3.2\%).
The association of age group with responses of positive systemic changes ( $n=559$ medical records) showed the following percentages: patients under the age of 20 $(4.7 \%), 20$ to $29(11.3 \%), 30$ to $39(16.8 \%), 40$ to 44 $(10 \%), 45$ to $49(10.9 \%), 50$ to $54(12.3 \%), 55$ to 59 $(12.9 \%), 60$ to $64(10.4 \%), 65$ to $69(4.8 \%)$, and older than 70 years old (5.9\%) (table 1 ).

Age group was standardized for a better understanding. It correlated the percentage obtained according to the presence of systemic changes to the total of patients assisted in each age group (table 2). This standardization showed that older age groups present higher prevalence of systemic changes (figure 2).

Another factor considered was postoperative surgical complication. A number of 91 complications were identified, from which 63 were from patients with systemic changes and 28 were from patients without systemic changes (table 3). The systemic changes resulting in higher rates of complications were bone diseases (40\%), asthma (33.3\%), mental disorders (22.5\%), alcoholism (16.7\%), rheumatic fever (15.4\%), and diabetes (13.8\%).

The complication with the highest prevalence was pain (34\%), followed by inflammation (19.8\%), hemorrhage (13.2\%), bone exposure (9.9\%), and alveolitis $(9.9 \%)$, as seen in table 4 .
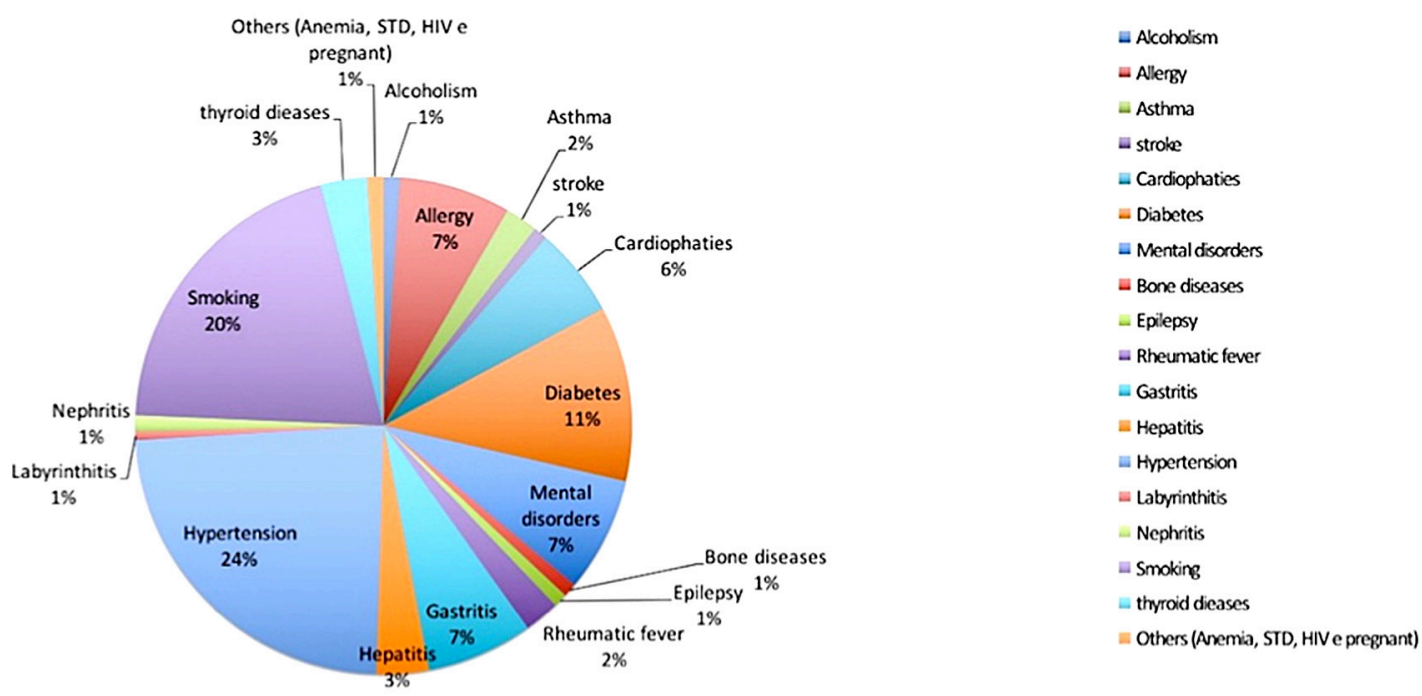

Figure 1. Preoperative systemic changes. 
Table 1. Preoperative systemic diseases and conditions related to the age group.

\begin{tabular}{|c|c|c|c|c|c|c|c|c|c|c|c|}
\hline Disease and Systemic condition/age range (years) & $<20$ & 20 a 29 & 30 a 39 & 40 a 44 & 45 a 49 & 50 a 54 & 55 a 59 & 60 a 64 & 65 a 69 & $>70$ & Total \\
\hline Alcoholism & & & 1 & 1 & 2 & & 2 & & & & 6 \\
\hline Allergy & 3 & 16 & 10 & 5 & 2 & 1 & 1 & 2 & & 1 & 41 \\
\hline Asthma & 5 & 3 & 1 & 1 & & 1 & & & 1 & & 12 \\
\hline AVC & & & & & 1 & 1 & 1 & & 1 & 1 & 5 \\
\hline Psychic disorders & 3 & 10 & 10 & 4 & 6 & 2 & 5 & & 1 & 1 & 42 \\
\hline Bone diseases & & & 1 & 1 & 2 & 1 & & & & & 5 \\
\hline Sexually transmitted diseases & 1 & & & & & 1 & & & & & 2 \\
\hline Epilepsy & & 2 & & 1 & 1 & & & 1 & & & 5 \\
\hline Hepatitis & 1 & 3 & 2 & 3 & 2 & 4 & 3 & 1 & & & 19 \\
\hline Hypertension & & 4 & 13 & 8 & 14 & 23 & 23 & 26 & 9 & 13 & 133 \\
\hline HIV & & & & & 1 & & & & & & 1 \\
\hline Labyrinthitis & & & & 1 & & 1 & & 1 & & & 3 \\
\hline Nephritis & & 1 & & 1 & 1 & 1 & 1 & 1 & & & 6 \\
\hline Smoking & 2 & 10 & 27 & 16 & 19 & 16 & 15 & 3 & 4 & 2 & 114 \\
\hline Thyroid Diseases & & 4 & 4 & & 1 & 1 & 4 & 1 & & 2 & 17 \\
\hline No alterations & 104 & 124 & 94 & 37 & 33 & 34 & 26 & 13 & 6 & 4 & 475 \\
\hline Total & 130 & 187 & 188 & 93 & 94 & 103 & 98 & 71 & 33 & 37 & 1038 \\
\hline
\end{tabular}

Table 2. Present/missing systemic changes related to the age group.

\begin{tabular}{|c|c|c|c|c|c|c|c|c|c|c|c|c|c|}
\hline Systemic & $\begin{array}{l}\text { Alteration/age } \\
\text { (Years) }\end{array}$ & range & $<20$ & 20 a 29 & 30 a 39 & 40 a 44 & 45 a 49 & 50 a 54 & 55 a 59 & 60 a 64 & 65 a 69 & $>70$ & Total \\
\hline Present & & & $\begin{array}{c}26 \\
(20 \%)\end{array}$ & $\begin{array}{c}63 \\
(33.7 \%)\end{array}$ & $\begin{array}{c}94 \\
(50 \%)\end{array}$ & $\begin{array}{c}56 \\
(60.2 \%)\end{array}$ & $\begin{array}{c}61 \\
(64.8 \%)\end{array}$ & $\begin{array}{c}69 \\
(66.7 \%)\end{array}$ & $\begin{array}{c}72 \\
(73.5 \%)\end{array}$ & $\begin{array}{c}58 \\
(81.7 \%)\end{array}$ & $\begin{array}{c}27 \\
(81.81 \%)\end{array}$ & $\begin{array}{c}33 \\
(81.2 \%)\end{array}$ & 559 \\
\hline Absence & & & $\begin{array}{c}104 \\
(80 \%)\end{array}$ & $\begin{array}{c}124 \\
(63.3 \%)\end{array}$ & $\begin{array}{c}94 \\
(50 \%)\end{array}$ & $\begin{array}{c}37 \\
(39.8 \%)\end{array}$ & $\begin{array}{c}33 \\
(35.1 \%)\end{array}$ & $\begin{array}{c}34 \\
(33.1 \%)\end{array}$ & $\begin{array}{c}26 \\
(26.5 \%)\end{array}$ & $\begin{array}{c}13 \\
(18.3 \%)\end{array}$ & $\begin{array}{c}6 \\
(18.2 \%)\end{array}$ & $\begin{array}{c}4 \\
(10.8 \%)\end{array}$ & 475 \\
\hline
\end{tabular}

The relationship between systemic change and type of complication (table 4) showed that alcoholism, bone diseases, and hepatitis presented the complication of inflammation. In addition, sinusitis presented alveolitis, thyroid diseases reported higher prevalence for pain, and rheumatic fever reported hemorrhage.

The complication related to asthma was alveolitis. In diabetic patients, the most frequent complications were alveolitis (50\%), bone exposure (25\%), and pain (25\%). In psychiatric patients, the main complications were pain $(66.7 \%)$ and local inflammation (33.3\%). Hypertensive patients reported pain $(45.4 \%)$ and inflammation $(9.1 \%)$ and described swelling complications (27.3\%) and hemorrhage (18.18\%) (table 4).

Another systemic condition with several complications was smoking, which was associated with inflammation 


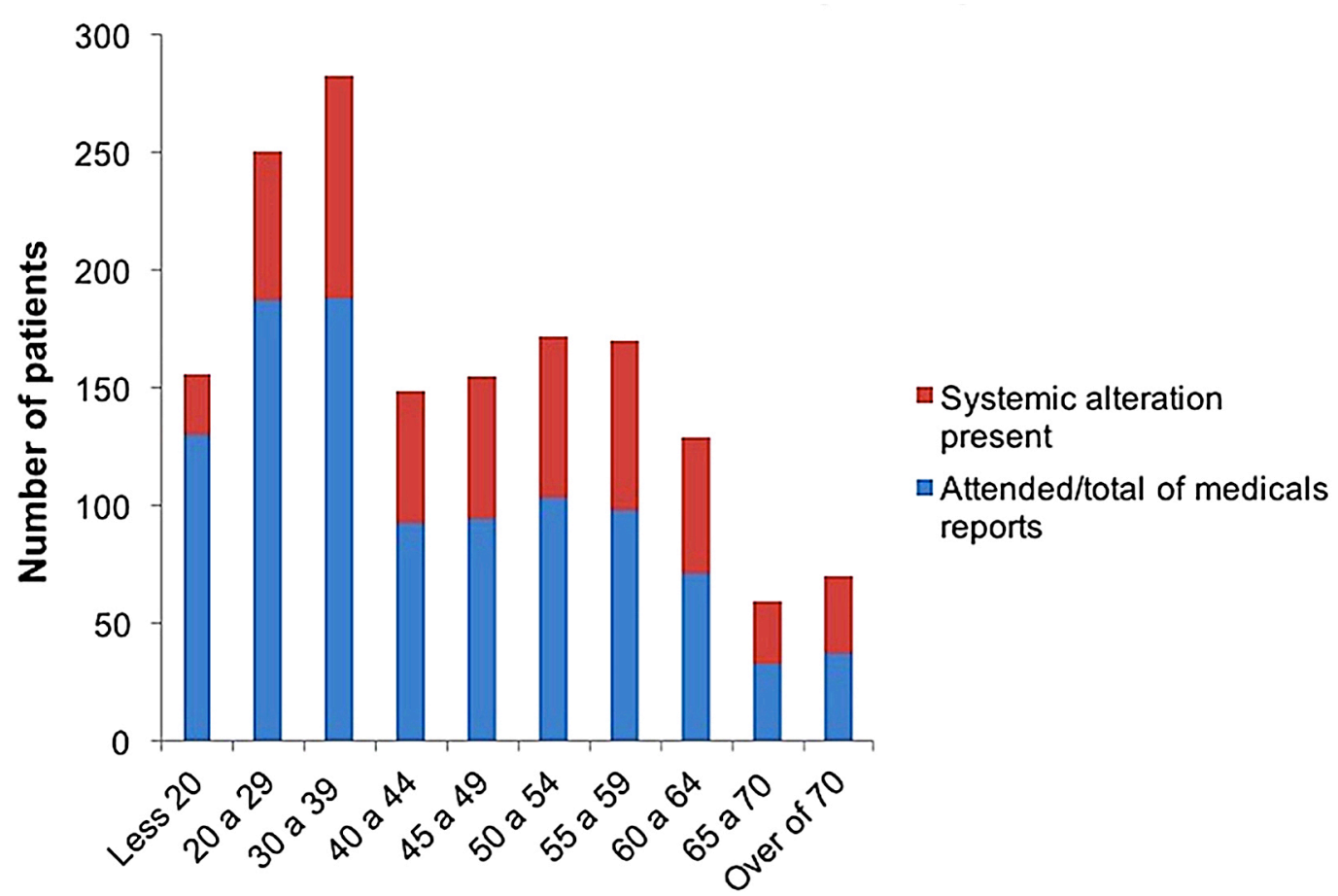

Age Range (years)

Figure 2. Presence of systemic alteration in relation to the age range.

$(53.33 \%)$, pain $(20 \%)$, hemorrhage $(13.3 \%)$, and oroantral communication (13.3\%). The complications reported in gastritis were inflammation (50\%), pain (25\%), and bone exposure $(25 \%)$. Cardiopathic patients reported pain (66.7\%) and bone exposure (33.3\%).

In patients who did not report any systemic change, the most frequent complication was pain (35.7\%), followed by hemorrhage (21.4\%), bone exposure (17.9\%), swelling $(7.1 \%)$, paresthesia $(7.1 \%)$, oroantral communication $(7.1 \%)$, and infection.

\section{DISCUSSION}

This study aimed to identify and quantify the prevalence of systemic diseases and to correlate them with postoperative surgical complications in patients subjected to dental surgical treatment. There was higher prevalence of patients with hypertension, smoking habits, and diabetes mellitus. The most prevalent complications in these changes were pain, inflammation, and alveolitis, respectively.
Information about the general health condition of patients should be collected prior to any dental treatment. However, this step is often neglected or performed inadequately and it may lead to incorrect surgical planning. This occurs mainly due to the lack of information about the presence of systemic diseases, which may lead to postoperative surgical complications [9-10]. Corroborating the authors in this study, information about systemic changes were not described in detail in the medical records of patients, as well as their postoperative data.

In this study, 992 medical records were evaluated, from which 559 (56.3\%) presented positive responses to systemic changes. This result is similar to the studies previously reported in the literature on prevalence $[7,9]$.

Among the systemic changes, hypertension was reported by $24 \%$ of patients, and similar results were obtained [7]. This pathology is progressively becoming one of the most serious public health problems. It is usually an asymptomatic disease and patients with this condition may not be controlled or not even be aware of the disease. Hence, authors emphasize the need for professionals to assess the blood pressure of patients before and after any 


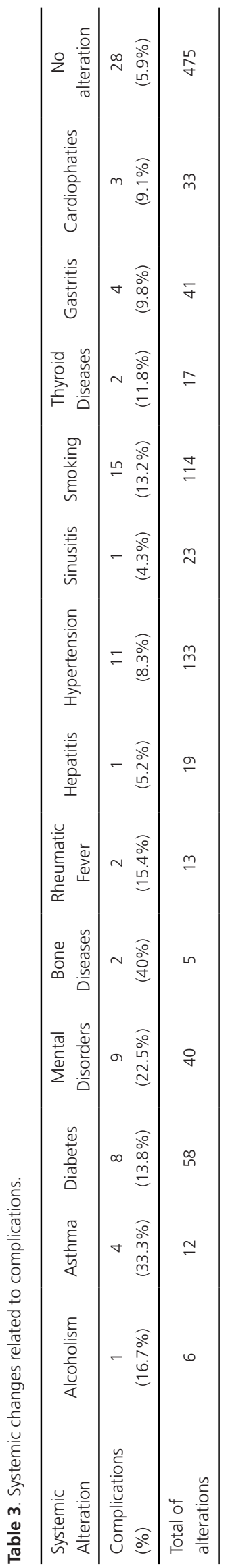

medical care procedure. The main complications related to this disease were pain $(45.4 \%)$, swelling (27.3\%), hemorrhage (18.2\%), and inflammation (9.1\%).

Smoking was the second highest indicator of systemic change in this study (20\%), predominantly in the age group of 30 to 39 years, and this result agrees with other studies [9]. Diagnostic complications associated with smoking included inflammation (53.3\%), pain (20\%), oroantral communication, and hemorrhage (13.3\%). Pain and inflammation are explained by the fact that nicotine decreases the activity of polymorphonuclear leukocytes, which contributes to an exacerbated inflammatory response and consequently an increase in painful symptoms. These results confirm previous studies and associate the pain complaint with the reduction of nicotine amount in the postoperative period [11]. Regarding oroantral communication, the literature has established that smoking affects bone repair negatively, because it reduces the nutrition of the maxillary sinus membrane and increases friability, posing a greater risk of perforation. This fact, added to the negative pressure on the oral cavity in the act of smoking, may rupture the Schneider membrane and cause oroantral communication $[12,13]$.

Diabetes mellitus was found in $11 \%$ of patients aged 30 to 39 years, presenting the diagnosed postoperative complications of alveolitis (50\%), bone exposure (25\%), and pain (25\%). Similar results were found in the literature review by Sousa et al. 2003 [14], in which $17 \%$ of patients presented diabetes mellitus in the age group of 25 to 44 years. These authors emphasized that altered glycogen normality decreases immune capacity and inflammatory response, as well as the vascular changes caused by the constant activation of polymorphonuclear cells, which makes individuals with this pathology more susceptible to infections and justifies the occurrence of the complications aforementioned.

In this study, only $2 \%$ of patients reported being asthmatic, which rate corroborates Przysiezny et al. [1], but it is considered low when compared to Queiroz et al. [9], who found $8 \%$ of patients with this pathology. These patients presented alveolitis as the main complication, and this was expected considering the treatment for this pathology includes the inhalation of corticoids, which particles are retained in the oral cavity and oropharynx and cause adverse effects such as candidiasis, pharyngitis, and 
Table 4. Systemic changes related to the types of complications.

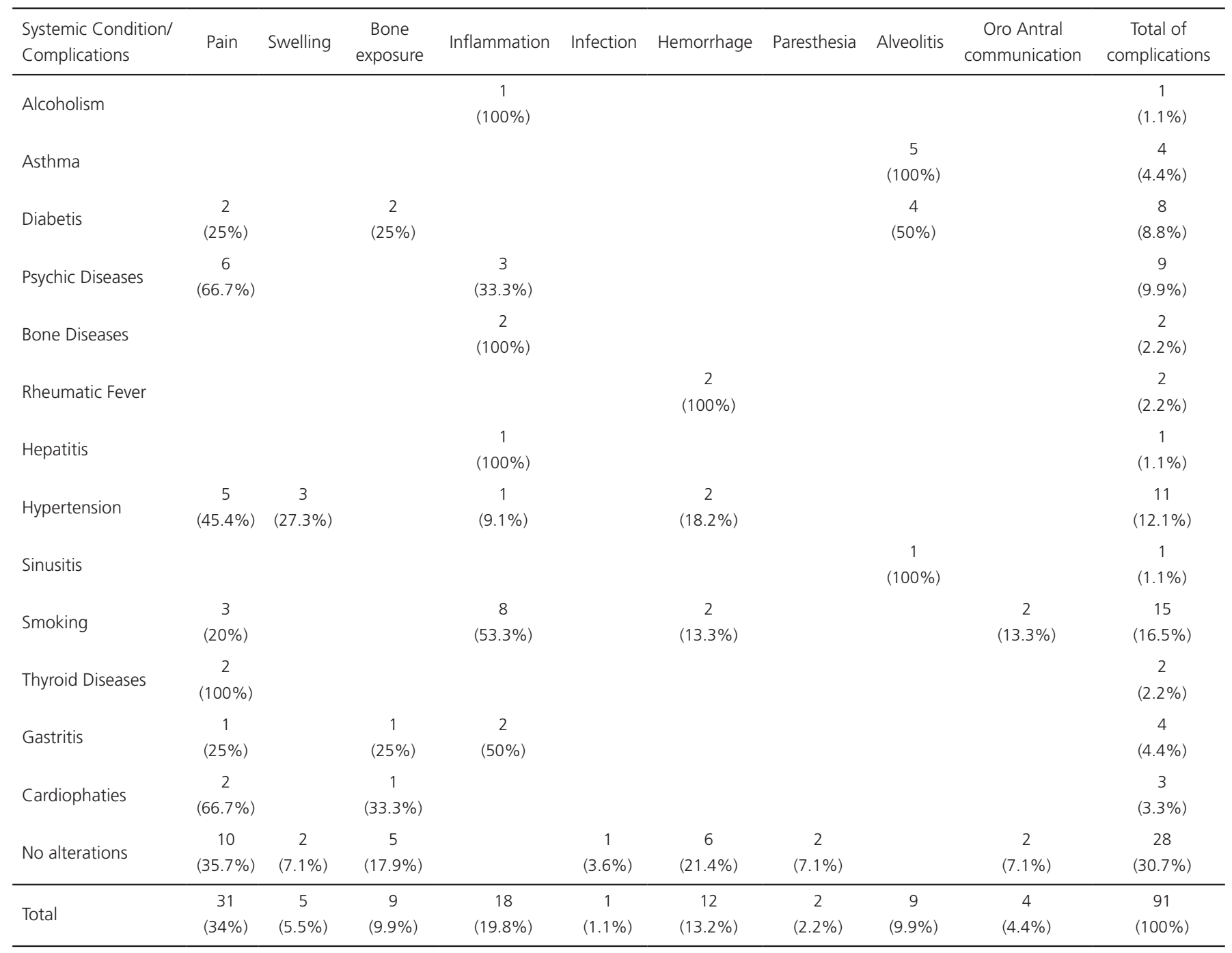

cough. Therefore, these medications become potential causal factors for developing alveolitis by increasing the amount of pathogens because of a humoral suppression from corticoids and by the adverse effect of cough that may be responsible for increased pressure in paranasal and oral cavities, which may lead to clot loss and the contamination of alveolar walls [15].

During the evaluation of results, it was noted that all patients, with and without systemic changes, reported the complication of pain. The perception of pain is subjective, influenced by affective and behavioral factors and experiences, and aggravated by emotional factors. Some authors [16-18] consider surgical procedures the main factors that may lead a patient to a painful experience, due to the tissue damages produced by incisions. During surgical procedures, such as tissue incisions, a tissue aggression is induced and it is responsible for releasing numerous chemical mediators through the activation of the arachidonic acid cascade, causing membrane phospholipids to be metabolized by cyclooxygenase (COX) and lipoxygenase (LOX). This causes the release of prostaglandins, prostacyclins, and leukotrienes, thus establishing a condition of inflammation with pain, swelling, and erythema [19].

Agreeing with the research described above in the present study, the patients with psychiatric pathologies who experience behavioral and emotional changes and use medications that act on the central nervous system, including benzodiazepines and tricyclic antidepressants, have reported painful symptomatology in the postoperative period of seven days. 
Complications such as pain, inflammation, and edema may be prevented and/or treated with the use of anti-inflammatories and analgesics. Romero-Reyes \& Uyanik [20] emphasize the role of the dental surgeon in controlling the pain expected by patients after surgical procedures, using medications to reduce stress and anxiety, as well as those that inhibit inflammatory cytokines responsible for the establishment of inflammation and its signs.

After inflammation is established, anti-inflammatory medication should be administered to accelerate the process of remission, which is naturally done by glucocorticoids (cortisol) [19]. Accordingly and correlating to the results for pain, inflammation, and swelling and their percentages, it is possible to raise the hypothesis of failure or inefficacy of pre- and postoperative medications. Further studies are required on the existence and type of medication used to prevent the complication and the efficacy of the medication designed to treat the inflammation and its signs and symptoms.

Even though this major topic is addressed in the first years of undergraduate studies, dental surgeons have been negligent, which reflects in complaints to health plans and legal proceedings, thus exposing the entire professional class. Therefore, dental surgeons must be fit to diagnose and conduct the dental treatment of their patients, avoiding any intercurrences and complications.

\section{CONCLUSION}

Based on the methodology, it was possible to conclude there was a relationship between postoperative complications and systemic changes, which main ones were pain-hypertension, inflammation-smoking, and alveolitis-diabetes. Thus, dental surgeons should pay particular attention to anamnesis, considering systemic changes are related directly to surgical complications.

\section{Collaborators}

EFS PIEDADE, acquisition of data: clinical/literature search; analysis and interpretation of data collected; final approval and guarantor of manuscript. JL GULINELLI, conception and design of study; drafting of article and/or critical revision; final approval and guarantor of manuscript. TP QUEIROZ, conception and design of study; drafting of article and/or critical revision; final approval and guarantor of manuscript. VM ROSA, acquisition of data: clinical/literature search; analysis and interpretation of data collected; final approval and guarantor of manuscript. PL Santos, conception and design of study; analysis and interpretation of data collected; final approval and guarantor of manuscript

\section{REFERENCES}

1. Przysiezny PE, Milanezi LA, Przysiezny LTS, Cordeiro FP. Perfil da situação sistêmica do paciente pré-exodontia em postos de saúde de Curitiba. Arch Oral Res. 2011;7:129-140. http:// dx.doi.org/10.7213/aor.v7i2.23111

2. Gadelha LA, Capalbo-da-Silva R, Lima VN, Momesso GAC, Queiroz SBF, Souza FA. Prevalência de doenças sistêmicas entre pacientes atendidos na Clínica Odontológica da Faculdade Católica Rainha do Sertão no município de Quixadá-CE. Arch Health Invest. 2017; 6(7):293-296. https://doi.org/10.21270/ archi.v6i7.2022

3. Kolte SV, Dolas RS, Shenoi R. Demographic Study of Prevalence of Systemic Diseases in Oral Maxillofacial Surgery Patients of Central India. J Maxillofac Oral Surg. 2014; 13: 267-270. https://doi.org/10.1007/s12663-013-0533-4

4. Peacock ME, Carson RE. Frequency of self-reported medical conditions in periodontal patients. J Periodontol. 1995; 66:1004-1007. https://doi.org/10.1902/jop.1995.66.11.1004

5. Sugerman PB, Barber MT. Patient Selection for Endosseous Dental Implants: Oral and Systemic Considerations. Int J Oral Maxillofac Implants. 2002; 17: 191-201.

6. Menin C. Avaliação de pacientes hipertensos na Clínica de Cirurgia do Terceiro Ano do Curso de Odontologia do Cesumar. Inic Cientif CESUMAR. 2006; 8(2):147-156.

7. Gaetti-Jardim EC, Pereira FP, Fattah CMR, Aranega AM. Prevalência e perfil epidemiológico das alterações sistêmicas em pacientes atendidos pelo serviço de cirurgia e traumatologia buco-maxilo-facial da Faculdade de Odontologia do Campus de Araçatuba - UNESP. Rev Odontol UNESP. 2008; 37:191-196.

8. Carvalho PSP, Mosete OL. Ocorrência de enfermidades ou condições sistêmicas detectadas após avaliação pré-operatória da saúde de 2.475 pacientes. Implant News. 2006; 3: 346-352.

9. Queiroz TP, Marques DO, Santos PL, Saraiva HC, Esteves JC, Hochuli-Vieira E. Prevalência de alterações sistêmicas em pacientes atendidos na disciplina de Cirurgia e Traumatologia Bucomaxilofacial do curso de Odontologia da UNIARA. Rev Odontol UNESP. 2012; 41:154-159.

10. Lockhart PB, Hong CHL, Diermen DEV. Systemic Diseases on the Diagnosis of Oral Diseases: A Problem-Based Approach. Dent Clin North Am. 2011; 1: 15-28. https://doi.org/10.1016/j. cden.2010.08.003

11. Creekmore FM, Lugo RA, Weiland KJ. Postoperative opiate analgesia requirements of smokers and nonsmokers. Ann Pharmacoth. 2004; 38: 949-953. https://doi.org/10.1345/aph. $1 \mathrm{D} 580$

12. Levin L, Schwartz-Arad D. The effect of cigarette smoking on dental implants and related surgery. Implant Dent. 2000; 
4:357-361. https://doi/org/10.1097/01.id.0000187956.592 76.18

13. Herzberg R, Dolev E, Schwartz-Arad D. Implant marginal bone loss in maxillary sinus graft. Int J Oral Maxillofac Implants. 2006; 21:103-110.

14. Sousa RR, Castro RD, Monteiro CH, Silva SC, Nunes AB. Buccal attendance of the patient with diabetes mellitus: a revision of literature. Pesq Bras Odontoped Clin Integr. 2003; 3: 71-77.

15. Santos NC, Jamelli S, Costa L, Filho CB, Medeiros D, Rizzo JA, Sarinho E. Assessing caries, dental plaque and salivary flow in asthmatic adolescents using inhaled corticosteroids. Allergol Immunopathol. 2012;40:220-224. https://doi.org/10.1016/j. aller.2011.04.005

16. Siviero M, Nhani VT, Prado EFGB. Análise da ansiedade como fator preditor de dor aguda em pacientes submetidos a exodontias ambulatorial. Rev Odontol UNESP. 2008; 37: 329-336.
17. Fattah CMRS, Aranega AM, Leal CR, Martinho J, Costa AR Controle da dor pós-operatória em cirurgia bucal: revisão de literatura. Rev Odontol Araçatuba. 2005; 26:56-62.

18. Rocha APC, Kraychete DC, Lemonica L, Carvalho LR, Barros Gam, Garcia JBS. Dor: Aspectos Atuais da Sensibilização Periférica e Central. Rev Bras Anestesiol. 2007; 57:94-105.

19. Kater CE. Programa de atualização em corticoterapia: maximizando o uso e minimizando o risco. Schering-Plough, 2001.

20. Romero-Reyes M, Uyanik JM. Orofacial pain management: current perspectives. J Pain Res. 2014 Feb 21;7:99-115. https://doi.org/10.2147/JPR.S37593

Received on: 14/1/2019

Final version resubmitted on: 10/4/2019

Approved on: 6/5/2019 